\title{
Comparative Study of High Temperature Oxidation Behaviour in AISI 304 and AISI 439 Stainless Steels
}

\author{
Antônio Claret Soares Sabioni ${ }^{\mathrm{a} *}$, Anne-Marie Huntz ${ }^{\mathrm{b}}$, Elizete Conceição da Luz $^{\mathrm{a}}$, \\ Marc Mantel ${ }^{\text {c }}$, Christian Haut ${ }^{\text {b }}$ \\ ${ }^{a}$ Laboratório de Difusão em Materiais/ Departamento de Física/ICEB - UFOP, \\ REDEMAT, 35400-000 Ouro Preto - MG, Brazil \\ b'Laboratoire d'Etude des Matériaux Hors-Équilibre - LEMHE, CNRS UMR 8647, \\ Université Paris XI, 91405, Orsay, France \\ ${ }^{\mathrm{c}}$ ACESITA S.A., 35180-018 Timóteo - MG, Brazil
}

Received: November 11, 2001; March 24, 2003

\begin{abstract}
This work deals with a comparison of high temperature oxidation behaviour in AISI 304 austenitic and AISI 439 ferritic stainless steels. The oxidation experiments were performed between 850 and $950{ }^{\circ} \mathrm{C}$, in oxygen and $\mathrm{Ar}\left(100 \mathrm{vpm} \mathrm{H}_{2}\right)$. In most cases, it was formed a $\mathrm{Cr}_{2} \mathrm{O}_{3}$ protective scale, whose growth kinetics follows a parabolic law. The exception was for the the AISI 304 steel, at $950{ }^{\circ} \mathrm{C}$, in oxygen atmosphere, which forms an iron oxide external layer. The oxidation resistance of the AISI 439 does not depend on the atmosphere. The AISI 304 has the same oxidation resistance in both atmospheres, at $850{ }^{\circ} \mathrm{C}$, but at higher temperatures, its oxidation rate strongly increases in oxygen atmosphere. Concerning the performance of these steels under oxidation, our results show that the AISI 439 steel has higher oxidation resistance in oxidizing atmosphere, above $850{ }^{\circ} \mathrm{C}$, while, in low $\mathrm{pO}_{2}$ atmosphere, the AISI 304 steel has higher oxidation resistance than the AISI 439, in all the temperature range investigated.
\end{abstract}

Keywords: oxidation, corrosion, AISI 304 stainless steel, AISI 439 stainless steel

\section{Introduction}

Chromia protective films which grow on stainless steels are very effective to reduce high temperature corrosion ${ }^{1,2}$. Among various applications, stainless steels are today widely used in exhaust line systems to improve the service life of automotive exhaust components, specially the upstream part of the exhaust line (manifold, down-pipe, converter shell), where temperatures can reach $1100{ }^{\circ} \mathrm{C}$.

Austenitic stainless steels like AISI 304 are traditionally used, but, recently, ferritic stainless steels have been developed for those applications. Besides offering advantage of lower costs than austenitic grades, due to the absence of nickel, they also present lower expansion coefficient than austenitic steels, which is a great advantage when temperature cycling resistance is needed.

In this work, the high temperature oxidation behaviour of an austenitic stainless steel type AISI 304 is compared to

*e-mail: sabioni@iceb.ufop.br

Trabalho apresentado no I Simpósio Mineiro de Ciências dos Materiais, Ouro Preto, Novembro de 2001. the behaviour of a $17 \%$ Cr ferritic stainless steel (AISI 439) containing titanium and niobium (see Table 1). These elements are generally added to stainless steels to prevent the risks of intergranular corrosion of weldments, due to the formation of stable titanium and niobium nitrides and carbides instead of non stable chromium carbides ${ }^{3,4}$.

Moreover due to additions of nitride and carbide forming elements, the structure of the stabilized $17 \% \mathrm{Cr}$ steels is "fully" ferritic at all temperatures. This property has a beneficial effect on the oxidation resistance of those steels, due to the absence of any ferrite to austenite phase transformation $^{5}$, which could damage the protective oxide film.

\section{Experimental}

The samples of AISI 304 austenitic and AISI 439 ferritic stainless steels used in this work were supplied by Acesita S.A. The chemical analysis of these steels are given in Table 1. 
For the thermogravimetric analyses, the samples were cut with dimensions of $10 \mathrm{~mm} \times 10 \mathrm{~mm} \times 0.6 \mathrm{~mm}$. A small hole of $0.8 \mathrm{~mm}$ in diameter was drilled near an edge in order to hang the sample in the thermobalance.

The samples were polished with diamond paste, and submitted to oxidation treatments in a thermobalance SETARAM TGDTA 92 , with sensibility of $\pm 1 \mu \mathrm{g}$.

The oxidation treatments were performed from 850 to $950^{\circ} \mathrm{C}$, either in oxygen or in $\mathrm{Ar}-\mathrm{H}_{2}\left(100 \mathrm{vpm} \mathrm{H}_{2}\right)$ atmospheres. The such obtained $\mathrm{Ar}-\mathrm{H}_{2}-\mathrm{H}_{2} \mathrm{O}$ mixture goes through a cryostat at $-60{ }^{\circ} \mathrm{C}$ which maintains an $\mathrm{H}_{2} \mathrm{O}$ pressure at $5.26 \times 10^{-6} \mathrm{~atm}$. Then, the $\mathrm{H}_{2} / \mathrm{H}_{2} \mathrm{O}$ equilibrium leads to low oxygen pressures equal to $1.46 \times 10^{-20} \mathrm{~atm}$ at $850{ }^{\circ} \mathrm{C}$, $1.38 \times 10^{-19} \mathrm{~atm}$ at $900{ }^{\circ} \mathrm{C}$, and $1.15 \times 10^{-18} \mathrm{~atm}$ at $950^{\circ} \mathrm{C}$. Oxidation treatments in air were not performed as it was observed that the oxygen pressure associated to air did not induce any change in the oxidation behaviour when compared to what occurs in $1 \mathrm{~atm}$ oxygen. Indeed, an oxygen pressure of $0.21 \mathrm{~atm}$ is sufficient to allow the formation of iron oxides.

The isothermal oxidation treatments were performed for $50 \mathrm{~h}$. The growth kinetics of the scales formed on the steels were established by measuring the mass gain per unit area versus oxidation time.

The microstructure and composition of the oxidized surface were examined by scanning electronic microscopy (SEM) and energy dispersive spectroscopy (EDX).

\section{Results}

\subsection{Kinetics}

Figure 1 shows the thermogravimetric analysis of the AISI 439 stainless steel during oxidation at $950{ }^{\circ} \mathrm{C}$, in oxygen atmosphere, for $50 \mathrm{~h}$. The plot of mass gain per unit area $(\Delta \mathrm{M} / \mathrm{S})$ against the oxidation time $(\mathrm{t})$ shown in Fig. 1 is typical for the steels studied in this work, except for the AISI 304 steel, above $850{ }^{\circ} \mathrm{C}$, in oxygen atmosphere.

Figure 2 shows the plot of $(\Delta \mathrm{M} / \mathrm{S})^{2}$ versus t corresponding to the thermogravimetric analysis shown in Fig. 1. In most cases, there was a linear relationship between $(\Delta \mathrm{M} / \mathrm{S})^{2}$ and $\mathrm{t}$, as shown in Fig. 2, indicating that the kinetics follow a parabolic law, according to the equation $(\Delta \mathrm{M} / \mathrm{S})^{2}=\mathrm{k}_{\mathrm{p}} \mathrm{t}$. Such a parabolic law traduces the fact that the oxide growth is controlled by diffusion ${ }^{6}$. The $\mathrm{k}_{\mathrm{p}}$ values are reported in Table 2 . The obtained $\mathrm{k}_{\mathrm{p}}$ values are representative of $\mathrm{Cr}_{2} \mathrm{O}_{3}$ growth ${ }^{6,7}$.

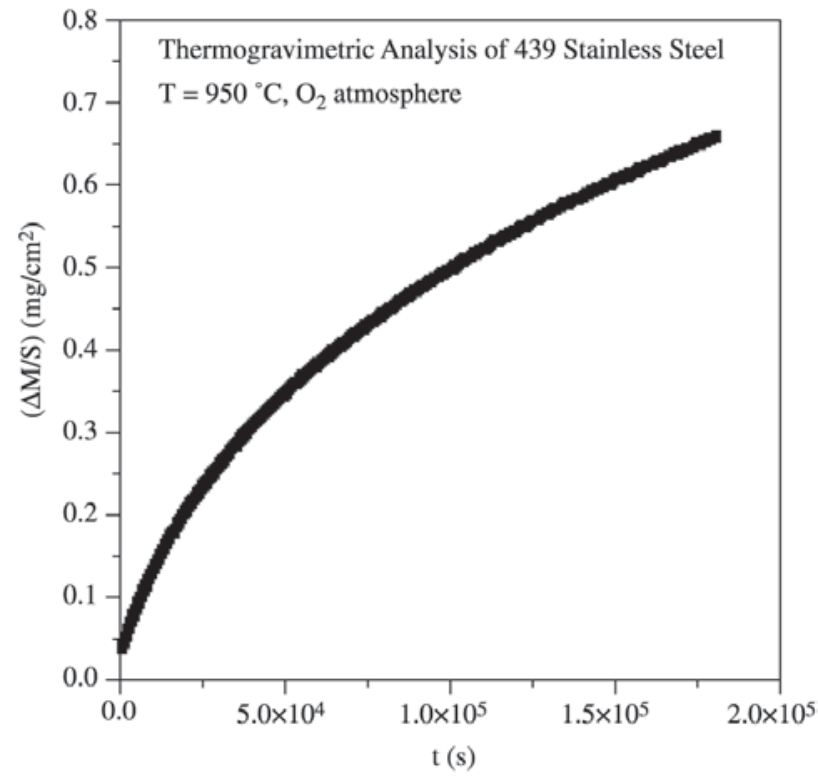

Figure 1. Evolution of the mass gain as a function of time for the 439 steel oxidized at $950{ }^{\circ} \mathrm{C}$ in oxygen.

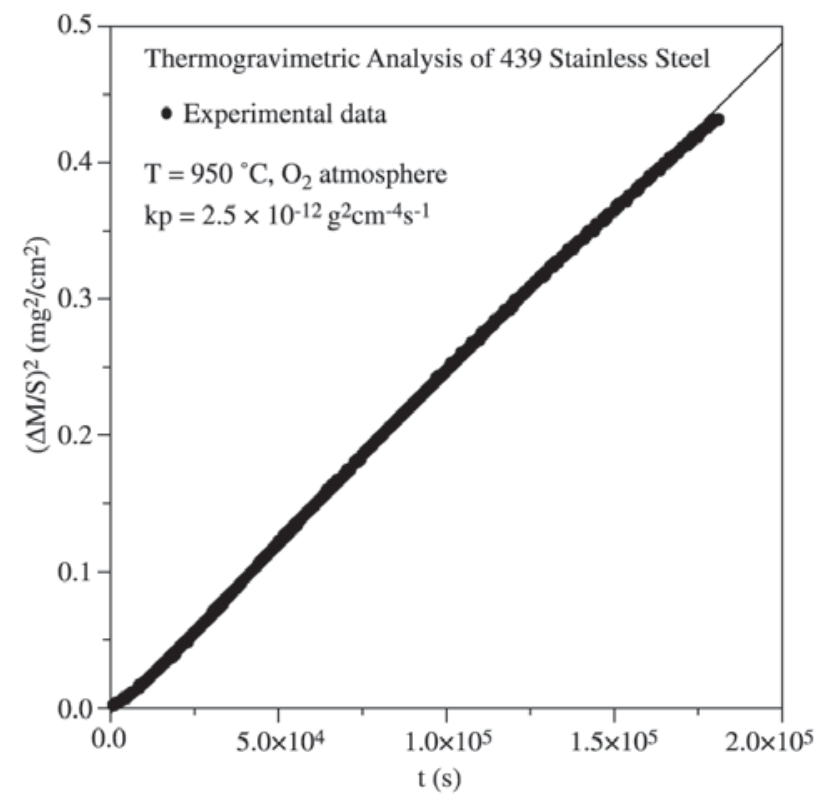

Figure 2. Quadratic plot of Fig. 1 showing that the oxidation kinetics obeys a parabolic law.

Table 1. Chemical Composition of the 304 and 439 Stainless Steels.

\begin{tabular}{lcccccccccc}
\hline Steel & $\mathrm{C}(\%)$ & $\mathrm{Mn}(\%)$ & $\mathrm{Si}(\%)$ & $\mathrm{P}(\%)$ & $\mathrm{S}(\%)$ & $\mathrm{Cr}(\%)$ & $\mathrm{Ni}(\%)$ & $\mathrm{Nb}(\%)$ & $\mathrm{Ti}(\%)$ & $\mathrm{N}(\mathrm{ppm})$ \\
\hline 304 & 0.0466 & 1.37 & 0.46 & 0.028 & 0.0006 & 18.07 & 8.11 & - & - & 322 \\
439 & 0.0060 & 0.18 & 0.42 & 0.033 & 0.0010 & 17.01 & 0.23 & 0.17 & 0.15 & 122 \\
\hline
\end{tabular}


Figure 3 shows the linearity deviation in a plot of $(\Delta \mathrm{M} / \mathrm{S})^{2}$ versus $\mathrm{t}$ for the AISI 304 steel oxidized at $950{ }^{\circ} \mathrm{C}$, in oxygen atmosphere. In this case, initially, there is formation of $\mathrm{Cr}_{2} \mathrm{O}_{3}$ scale $\left(\mathrm{k}_{\mathrm{p} 1}\right.$ value in Table 2$)$ followed by the formation of an iron oxide scale, little adherent, which results in high oxidation rate $\left(\mathrm{k}_{\mathrm{p} 2}\right.$ value in Table 2). Such behavior is not found when the samples are oxidized in $\mathrm{Ar}-\mathrm{H}_{2}-\mathrm{H}_{2} \mathrm{O}$.

\subsection{Oxide morphology}

Concerning the 439 stainless steel, the oxide scale is always made of chromia in the temperature range or the oxidation atmosphere investigated, with some titanium and manganese oxides. This is shown by Fig. 4, which corresponds to EDX analysis on the outer surface of the scale formed at $950{ }^{\circ} \mathrm{C}$ in oxygen. The same behavior is observed at lower temperatures. When oxidized in $\mathrm{Ar}-\mathrm{H}_{2}-\mathrm{H}_{2} \mathrm{O}$, some

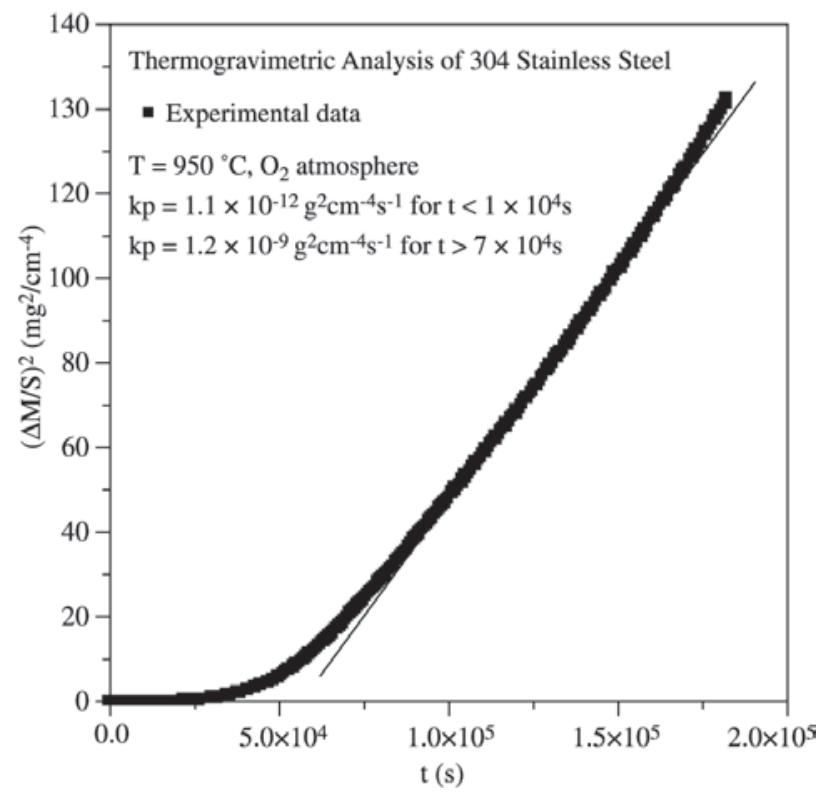

Figure 3. Quadratic plot of the mass gain versus time for the 304 steel oxidized at $950{ }^{\circ} \mathrm{C}$ in oxygen, showing two oxidation stages, a slow first one and a second much more fast. spallings appear at $950^{\circ} \mathrm{C}$, and at the bottom of the spalled zone, oxide crystallites made of $\mathrm{Si}$ and $\mathrm{Ti}$ are detected (Fig. 5). For oxidation in $\mathrm{Ar}-\mathrm{H}_{2}-\mathrm{H}_{2} \mathrm{O}$ but at $900{ }^{\circ} \mathrm{C}$ or $850^{\circ} \mathrm{C}$, some whiskers are detected, as shown by Fig. 6 .

The situation differs for 304 steel. In $\mathrm{Ar}-\mathrm{H}_{2}-\mathrm{H}_{2} \mathrm{O}$ atmosphere, the scale is made of chromia but, specially at 850 and $900{ }^{\circ} \mathrm{C}$, extrusions are observed all along the substrate grain-boundaries (Fig. 7a), and these extrusions are made mainly of whiskers (Fig. 7b) rich in $\mathrm{Cr}$ and $\mathrm{Mn}$.

On transverse sections, it is possible to observe silica at the metal-oxide interface, under the chromia layer (Fig. 8). When the 304 steel is oxidised in $\mathrm{O}_{2}$, the scale is made of chromia plus Mn oxide at 850 and $900{ }^{\circ} \mathrm{C}$, but at $950{ }^{\circ} \mathrm{C}$, the scale is made of an outer layer of iron oxide (Fig. 9a) whose aspect differs of the aspect given by the chromia layer which is observed when spalling of the outer layer occurs (Fig. 9b).

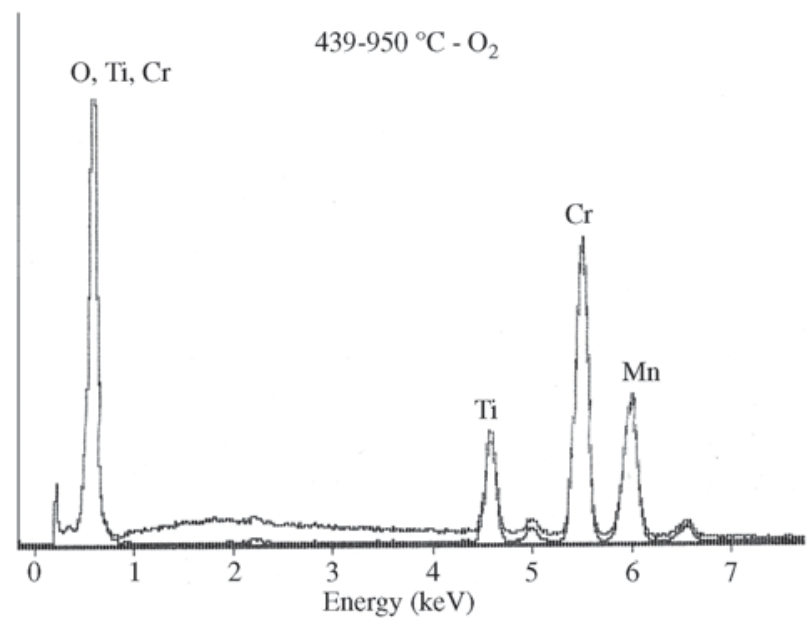

Figure 4. EDX analysis on the surface of the 439 steel oxidized at $950{ }^{\circ} \mathrm{C}$ in oxygen showing that the oxide scale contains $\mathrm{Cr}$, Ti and $\mathrm{Mn}$.

Table 2. Parabolic oxidation constants.

\begin{tabular}{lcccc}
\hline & \multicolumn{2}{c}{ 439 Stainless steel } & \multicolumn{2}{c}{304 Stainless steel } \\
\hline $\begin{array}{l}\text { Atmosphere } \rightarrow \\
\text { Temperature }\left({ }^{\circ} \mathrm{C}\right)^{-}\end{array}$ & $\mathrm{O}_{2}$ & $\mathrm{Ar}_{2} \mathrm{H}_{2}$ & $\mathrm{O}_{2}$ & $\mathrm{Ar}-\mathrm{H}_{2}$ \\
850 & $\mathrm{k}_{\mathrm{p}}\left(\mathrm{g}^{2} \mathrm{~cm}^{-4} \mathrm{~s}^{-1}\right)$ & $\mathrm{k}_{\mathrm{p}}\left(\mathrm{g}^{2} \mathrm{~cm}^{-4} \mathrm{~s}^{-1}\right)$ & $\mathrm{k}_{\mathrm{p}}\left(\mathrm{g}^{2} \mathrm{~cm}^{-4} \mathrm{~s}^{-1}\right)$ & $\mathrm{k}_{\mathrm{p}}\left(\mathrm{g}^{2} \mathrm{~cm}^{-4} \mathrm{~s}^{-1}\right)$ \\
900 & $3.2 \times 10^{-13}$ & $2.9 \times 10^{-13}$ & $1.3 \times 10^{-13}$ & $1.6 \times 10^{-13}$ \\
950 & $1.4 \times 10^{-12}$ & $1.5 \times 10^{-12}$ & $6.2 \times 10^{-12}$ & $3.0 \times 10^{-13}$ \\
& $2.5 \times 10^{-12}$ & $2.6 \times 10^{-12}$ & $\mathrm{t}<10^{4} \mathrm{~s}: 1.1 \times 10^{-12}\left(\mathrm{kp}_{1}\right)$ & $6.4 \times 10^{-13}$ \\
\hline
\end{tabular}




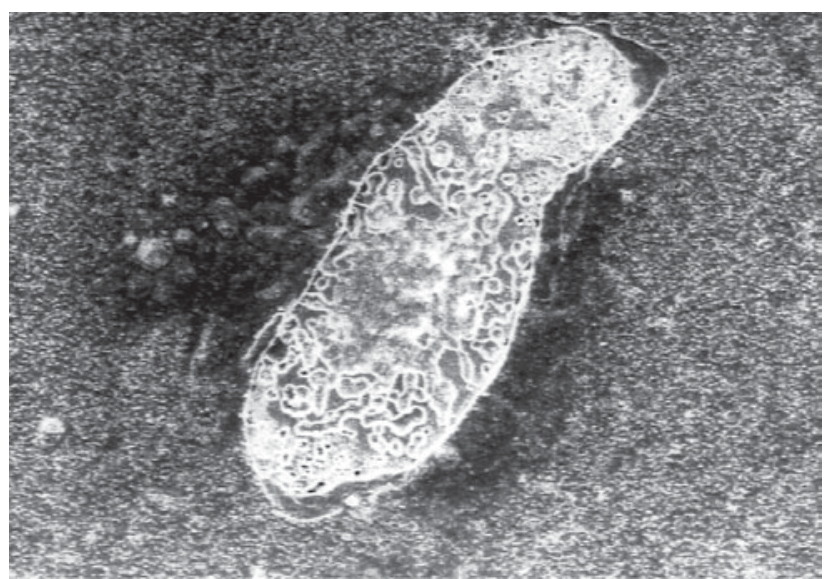

Figure 5. Observation of a spalled zone by SEM on the 439 steel oxidized at $950{ }^{\circ} \mathrm{C}$ in $\mathrm{Ar}-\mathrm{H}_{2}-\mathrm{H}_{2} \mathrm{O}$ for $50 \mathrm{~h}(275 \mathrm{x})$.

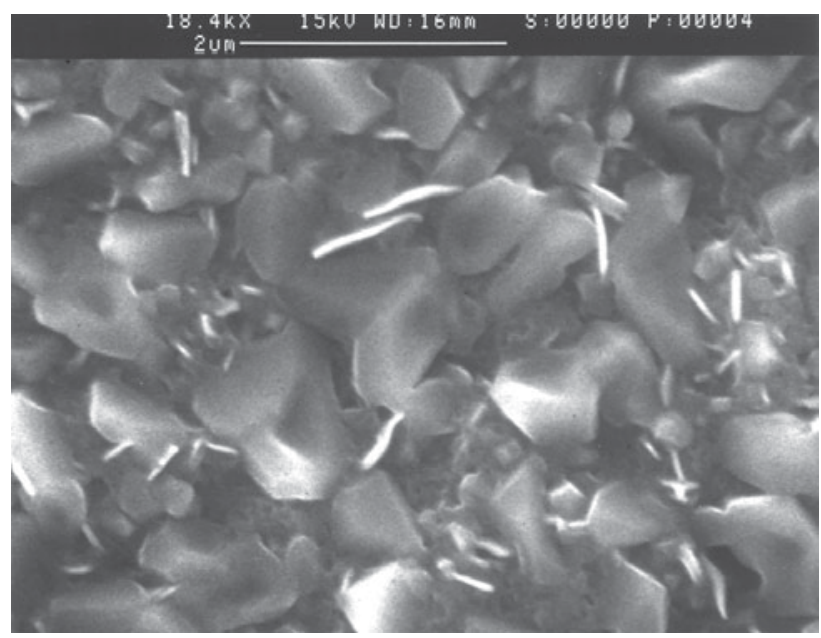

Figure 6. Observation of the surface of the oxidized 439 steel after $50 \mathrm{~h}$ at $850{ }^{\circ} \mathrm{C}$ in $\mathrm{Ar}-\mathrm{H}_{2}-\mathrm{H}_{2} \mathrm{O}$ mixture $(18400 \times)$.

\section{Discussion}

Figure 10 shows a comparison of the oxidation rates of the AISI 439 steel in low $\mathrm{pO}_{2}$ atmosphere and in oxidizing atmospheres. For this steel, the oxidation rate has no significant dependence on both atmospheres used. In all cases, chromium oxide is formed. In $\mathrm{Ar}-\mathrm{H}_{2}-\mathrm{H}_{2} \mathrm{O}$ mixture, iron oxides are thermodynamically unstable while $\mathrm{Cr}_{2} \mathrm{O}_{3}$ is stable $^{2}$, consequently only this chromium oxide can grow. In oxygen atmosphere, all oxides (iron and chromium oxides) are thermodynamically stable and the scale growth is then controlled by kinetic factors. $\mathrm{Cr}_{2} \mathrm{O}_{3}$ is always the most stable oxide, but its growth as a continuous film will be possible if the chromium amount is higher than a critical value given by ${ }^{6}$ :

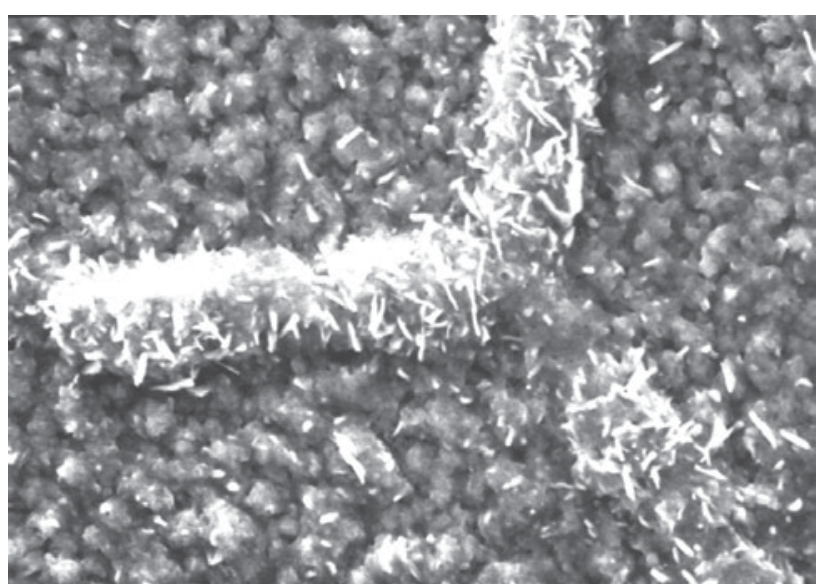

(a)

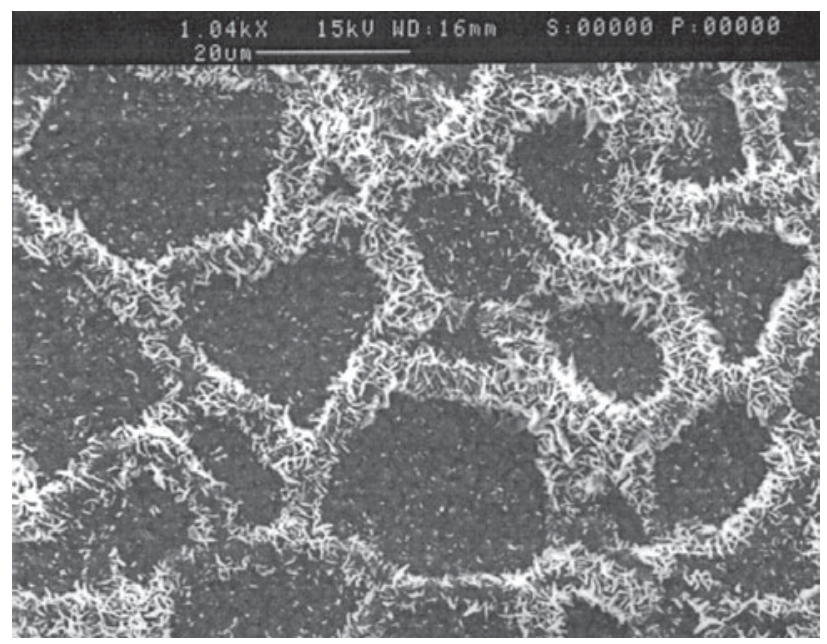

(b)

Figure 7. Observation of the surface of oxidized 304 steel. a) in $\mathrm{Ar}-\mathrm{H}_{2}-\mathrm{H}_{2} \mathrm{O}$ at $850{ }^{\circ} \mathrm{C}(4470 \times)$; b) in $\mathrm{Ar}-\mathrm{H}_{2}-\mathrm{H}_{2} \mathrm{O}$ at $900{ }^{\circ} \mathrm{C}(1040 \times)$.

$$
\mathrm{N}_{\mathrm{Cr}}^{\mathrm{Min}}=\mathrm{F}\left[\left(\frac{1}{2} \frac{\mathrm{k}_{\mathrm{c}}\left(\mathrm{Cr}_{2} \mathrm{O}_{3}\right)}{\tilde{\mathrm{D}}}\right)^{1 / 2}\right]
$$

where

$$
F(u)=p^{1 / 2} u(1-\operatorname{erf} u) \exp \left(u^{2}\right)
$$

with

$$
\operatorname{erf} u=\frac{2}{\sqrt{\pi}} \int_{0}^{u} e^{-u^{2}} d u
$$




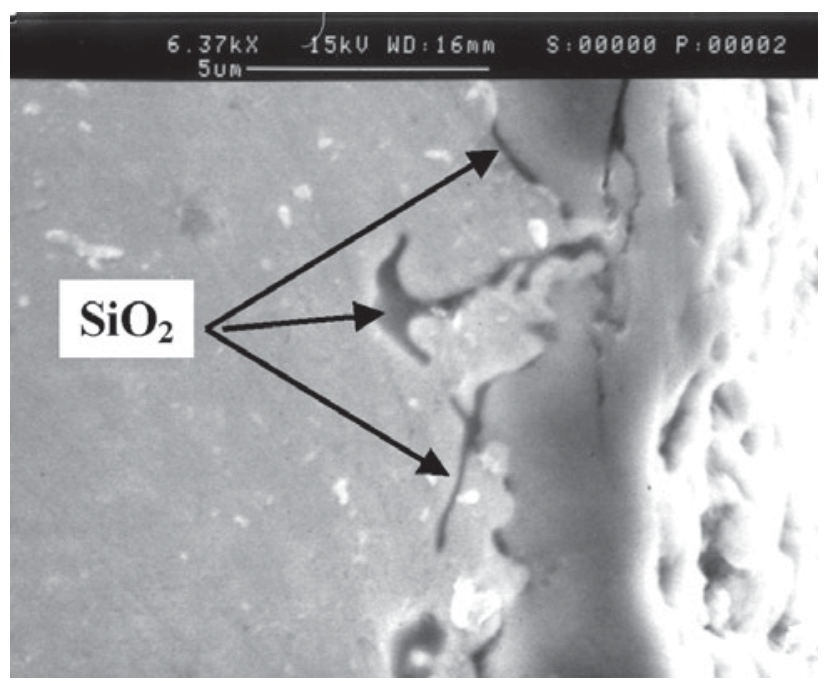

Figure 8. Transverse section showing the inner chromia scale with silica at the bottom (dark zones). Oxidation of 304 steel for $50 \mathrm{~h}$ at $950{ }^{\circ} \mathrm{C}$ in $\mathrm{O}_{2}$.

$\mathrm{k}_{\mathrm{c}}\left(\mathrm{Cr}_{2} \mathrm{O}_{3}\right)$ is the parabolic oxidation constant of chromia expressed in $\mathrm{cm}^{2} / \mathrm{s}$, and $\tilde{\mathrm{D}}$ is the interdiffusion coefficient in the metallic substrate.

For an oxide $\mathrm{M}_{\mathrm{a}} \mathrm{O}_{\mathrm{b}}, \mathrm{k}_{\mathrm{c}}$ is related to $\mathrm{k}_{\mathrm{p}}$ (Table 2) by:

$$
\mathrm{k}_{\mathrm{c}}=\left(\frac{\mathrm{M}_{\mathrm{ox}}}{\mathrm{b} \rho_{\mathrm{ox}} \mathrm{M}_{\mathrm{o}}}\right) \mathrm{k}_{\mathrm{p}}
$$

where the subscript "ox" and "o" are relative to the oxide and the oxygen species, respectively, $\mathrm{M}$ is the molar mass and $\rho$ the volumetric mass.

Moulin ${ }^{8}$ gives a value of $\mathrm{N}_{\mathrm{Cr}}^{\mathrm{Min}}$ around 0.15 at $900{ }^{\circ} \mathrm{C}$. Thus the chromium amount in the 439 steel is higher than this value and a chromia layer can form, as soon as the oxidation begins, as a continuous layer. In such conditions, iron oxides do not grow. Moreover the activation energy of oxidation, calculated from the slope of the curves in Fig. 10, is equal to $\approx 250 \mathrm{~kJ} / \mathrm{mol}$, which is a value given in the literature for some chromia film growth ${ }^{9,10}$.

The plot of Fig. 11 shows the influence of the atmosphere on the oxidation rate of the AISI 304 steel. At $850^{\circ} \mathrm{C}$, there is no significative effect of the atmosphere, due to the formation of $\mathrm{Cr}_{2} \mathrm{O}_{3}$ in both cases. However, at higher temperatures, the oxidation rate of this steel, in oxygen atmopshere, is much greater than in $\mathrm{Ar}-\mathrm{H}_{2}-\mathrm{H}_{2} \mathrm{O}$ atmosphere on account of formation of iron oxide. For oxygen pressures imposed by the $\mathrm{Ar}-\mathrm{H}_{2}-\mathrm{H}_{2} \mathrm{O}$ mixture, iron oxides are thermodynamically unstable ${ }^{2}$, while chromia is stable. Thus, only this oxide appears in $\mathrm{Ar}-\mathrm{H}_{2}-\mathrm{H}_{2} \mathrm{O}$. When the oxygen pressure is sufficient to form chromium and iron oxides, i.e., in $1 \mathrm{~atm}$ oxygen, the diffusion coefficients in the auste-

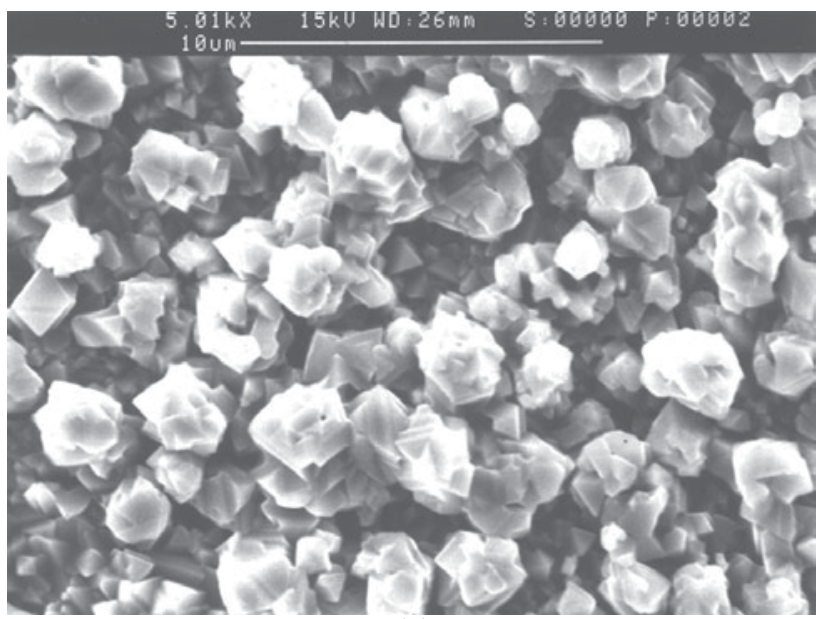

(a)

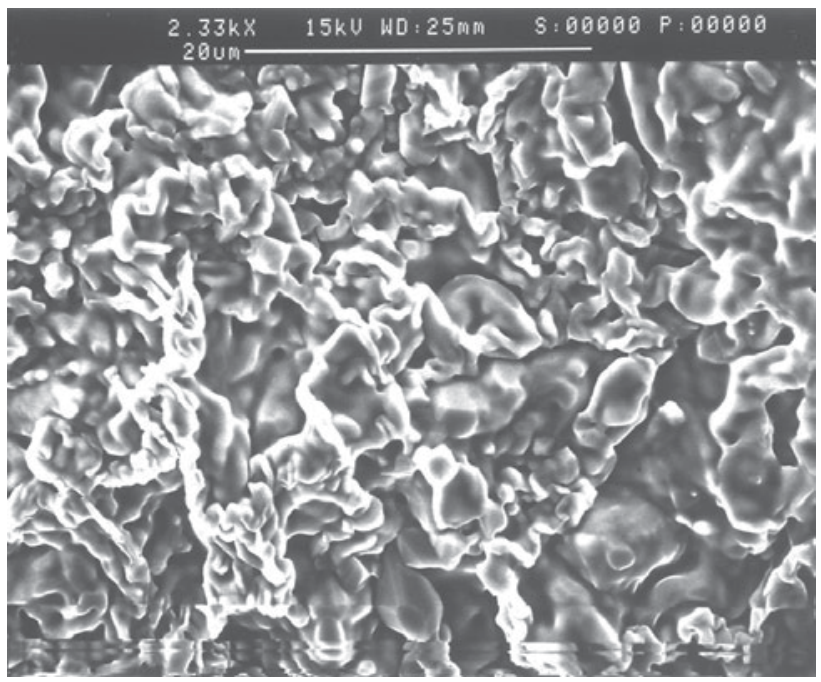

(b)

Figure 9. Observation of the surface of the 304 steel oxidized in oxygen at $950{ }^{\circ} \mathrm{C}$ : a) bottom of a spalled zone: chromium oxide; b) unspalled surface, iron oxide.

nitic substrate being smaller than in the previous case (D in ferritic steel is fairly 10 times higher than in an austenitic steel), the minimum content of chromium, given by Eq. 1, can become higher than the chromium amount in the 304 steel. This seems to be the case, at least at $950{ }^{\circ} \mathrm{C}$, and iron oxides appear simultaneously to chromia. It can be noted that the activation energy of chromia growth (see Table 3) for 304 steel in $\mathrm{Ar}-\mathrm{H}_{2}-\mathrm{H}_{2} \mathrm{O}$ equal to $156 \mathrm{~kJ} / \mathrm{mol}$ (Figs. 11 and 13), as found by some authors ${ }^{11,12}$, is smaller than the activation energy for chromia growth on the 439 steel whose activation energy associated to chromia growth is about

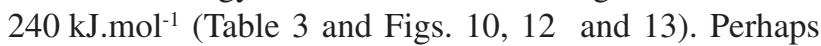


Table 3. Activation energies for oxidation.

\begin{tabular}{ccc}
\hline & \multicolumn{2}{c}{ Activation Energy $(\mathrm{kJ} / \mathrm{mol})$} \\
Atmosphere & 304 Steel & 439 Steel \\
\hline $\mathrm{O}_{2}$ & "1052"* & 237 \\
$\mathrm{Ar}-\mathrm{H}_{2}-\mathrm{H}_{2} \mathrm{O}$ & 156 & 251 \\
\hline
\end{tabular}

* this value is not significant as the oxide formed differs at low an high temperature.

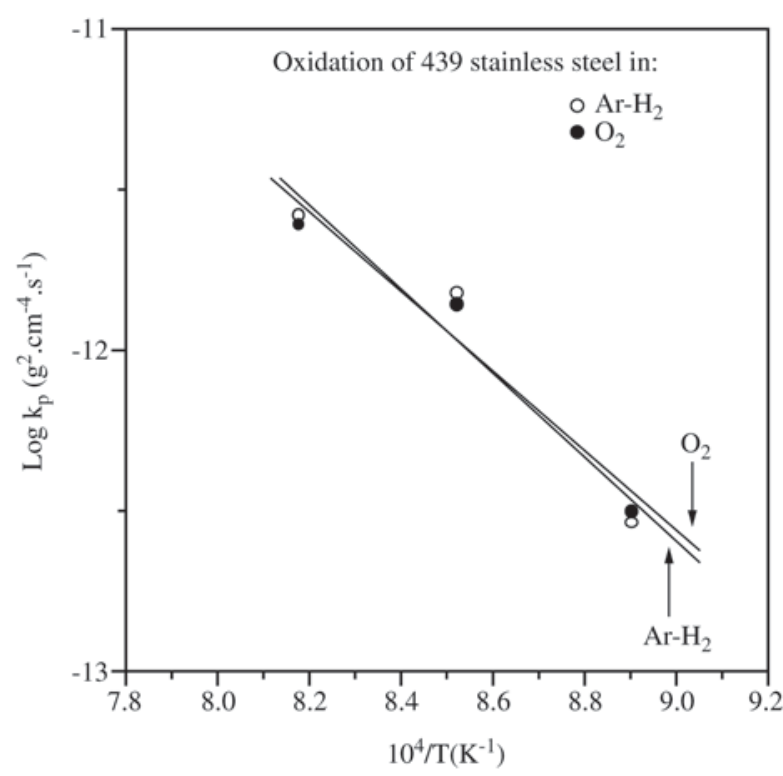

Figure 10. Arrhenius plot of the parabolic oxidation constants of 439 steel in oxygen and in $\mathrm{Ar}-\mathrm{H}_{2}-\mathrm{H}_{2} \mathrm{O}$ atmospheres.

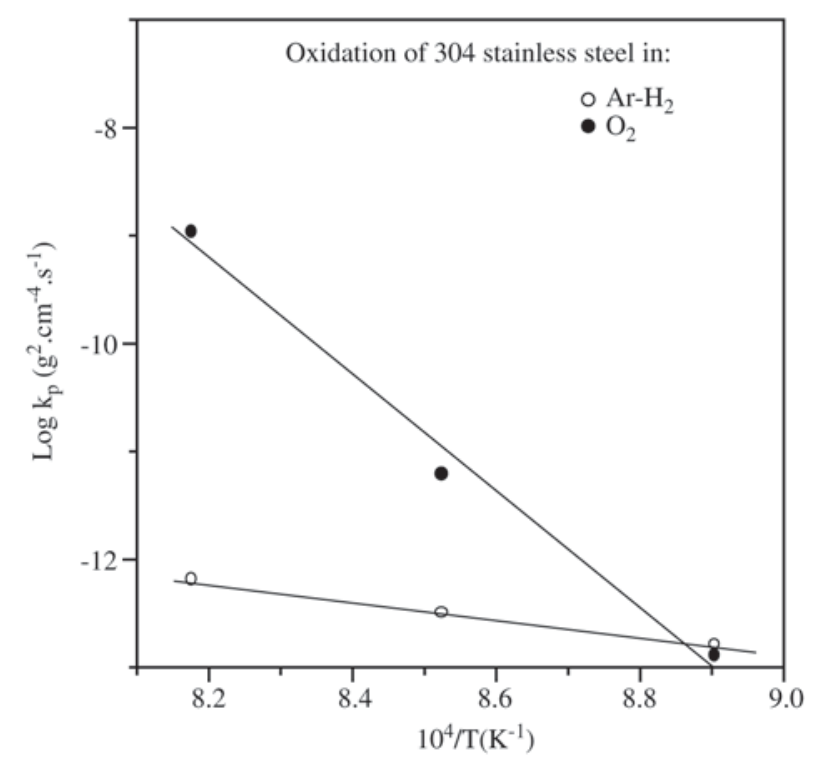

Figure 11. Arrhenius plot of the parabolic oxidation constants of 304 steel in oxygen and in $\mathrm{Ar}-\mathrm{H}_{2}-\mathrm{H}_{2} \mathrm{O}$ atmospheres. this difference is associated to manganese which is more present in 304 steel and which is a very oxidizable element (more oxidizable than chromium). Simultaneously to the difference in the activation energy, the oxidation rate of 304 steel in $\mathrm{Ar}-\mathrm{H}_{2}-\mathrm{H}_{2} \mathrm{O}$ is smaller than the oxidation rate of 439 steel, in all temperature range investigated as shown by

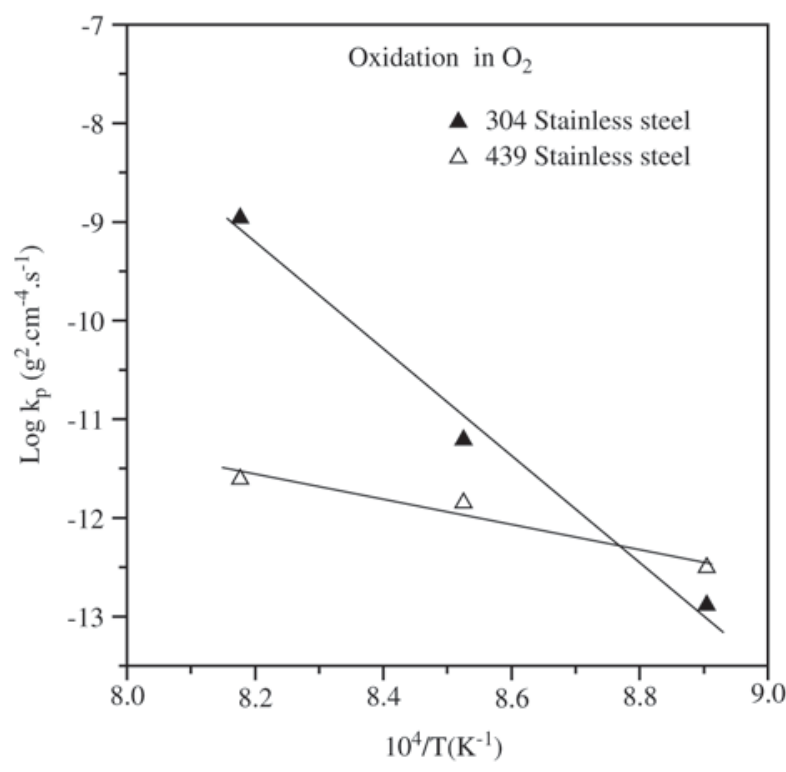

Figure 12. Arrhenius plot of the parabolic oxidation constants of 304 and 439 steels in oxygen.

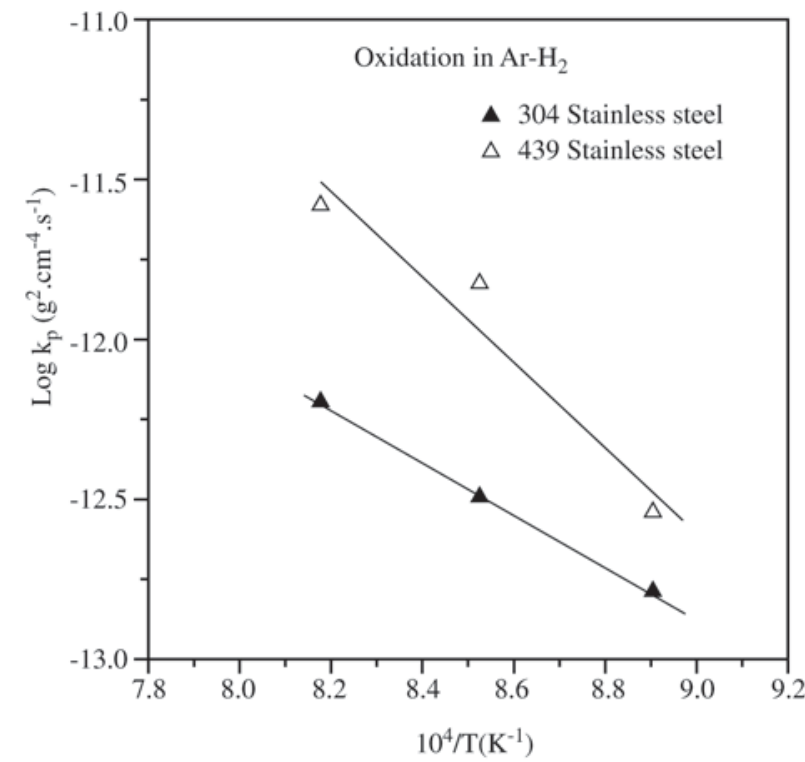

Figure 13. Arrhenius plot of the parabolic oxidation constants of 304 and 439 steels in $\mathrm{Ar}-\mathrm{H}_{2}-\mathrm{H}_{2} \mathrm{O}$. 
Fig. 13. This suggests that oxidation of Mn reduces iron oxidation and incorporation in the chromia scale. In other words, the presence of $\mathrm{Mn}$ seems to promote the formation of a continuous chromia scale. Nevertheless, an effect of the oxygen pressure decrease on the chromia growth rate cannot be excluded ${ }^{13}$.

The plots of Figs. 12 and 13 are a comparison of the oxidation behaviour of the AISI 304 and AISI 439 steels, between 850 and $950{ }^{\circ} \mathrm{C}$, in oxygen and in $\mathrm{Ar}-\mathrm{H}_{2}-\mathrm{H}_{2} \mathrm{O}$ atmosphere, respectively. In oxygen, it is clear that above $850{ }^{\circ} \mathrm{C}$, the AISI 304 steel has less oxidation resistance than the AISI 439 steel. Again, this is related to the fact that, at $950{ }^{\circ} \mathrm{C}$, a protective chromia layer is formed only on the 439 ferritic steel. The growth of iron oxides on the 304 steel must already begin at $900^{\circ} \mathrm{C}$. In Ar- $\mathrm{H}_{2}$, Fig. 13 clearly shows that the austenitic AISI 304 steel has higher oxidation resistance than the ferritic AISI 439 steel in low $\mathrm{pO}_{2}$ atmosphere. Perhaps it is related to the presence of $\mathrm{Nb}$ and $\mathrm{Ti}$ in the 439 steel which can promote spallings (see Fig.5). The spallings induce fast re-oxidation of the bare substrate. Moreover, in the temperature range from 850 to $950{ }^{\circ} \mathrm{C}$, the AISI 304 steel forms an homogeneous scale of $\mathrm{Cr}_{2} \mathrm{O}_{3}$, in which grain-boundaries of the substrate are decorated by whiskers of $\mathrm{Cr}$ oxide containing $\mathrm{Mn}$. Mn seems to have rather a favourable effect.

\section{Conclusions}

- A comparative study of high temperature oxidation behaviour in AISI 304 and AISI 439 stainless steels was performed between 850 and $950{ }^{\circ} \mathrm{C}$, in oxygen and $\mathrm{Ar}-\mathrm{H}_{2}-\mathrm{H}_{2} \mathrm{O}\left(100 \mathrm{vpm} \mathrm{H}_{2}\right)$ atmospheres.

- Concerning the effect of the atmosphere on oxidation behaviour of each steel, our results show that: The oxidation resistance of the AISI 439 does not depend on the atmosphere. On the other hand, the AISI 304 steel has the same oxidation behaviour in both atmospheres, at $850^{\circ} \mathrm{C}$, but, at higher temperatures, its oxidation rate dramatically increases in oxygen atmosphere, in comparison to that observed in $\mathrm{Ar}-\mathrm{H}_{2}-\mathrm{H}_{2} \mathrm{O}$ atmosphere.

- Concerning the performance of the steels under oxidation, our results show that: The AISI 439 steel has higher oxidation resistance than the AISI 304, in oxidizing atmosphere, for temperatures above $850{ }^{\circ} \mathrm{C}$, while the AISI 304 steel has higher oxidation resist- ance than the AISI 439, in low $\mathrm{pO}_{2}$ atmosphere, in all the temperature range investigated.

- In most cases, a $\mathrm{Cr}_{2} \mathrm{O}_{3}$ protective scale was formed, whose growth kinetics follows a parabolic law. The exception was for the AISI 304 steel, at $950{ }^{\circ} \mathrm{C}$, in oxygen atmosphere, which forms an iron oxide external scale, non-adherent, which results in a higher oxidation rate.

\section{Acknowledgments}

The authors are grateful to CNPq (Brazil) and CNRS (France) for financial support.

\section{References}

1. Landolt, D. "Corrosion et Chimie de Surface des Métaux", Traité des Matériaux, Presses Polytechniques et Universitaires Romandes, 1997.

2. Clolson, J.C.; Dabosi, F. "Corrosion des Matériaux à Haute Température", Ed. G. Béranger, Les Editions de Physique, Ecole d'hiver du CNRS, 1985.

3. Mantel, M.; Baroux, B.; Ragot, J.; Chemelle, P. Mémoire et Etudes Scientifiques, Revue de Métallurgie, p. 637-648, 1990.

4. Fujita, N.; Ohmura, K.; Kikuchi, M.; Suzuki, T.; Funaki, S.; Hirishige, I. Scripta Met., n. 32 (5/6), p. 449-469, 1989.

5. Baïlon, J.P.; Dorlot, J.M. "Des Matériaux", Presses Internationales Polytechniques, 2000.

6. Huntz, A.M. "Diffusion dans les couches d'oxydes", Ecole d'Hiver Franco/Latino Americana de "Diffusion dans les Matériaux", Ed. Philibert, J., Sabioni, A.C.S., Dyment, F., Ouro-Preto, M.G., Brasil, n. 17-29, p. 315-338, juillet 1994; Huntz, A.M. Journal de Physique III, France, n. 5, p. 1729-1757, 1995.

7. Atkinson, A. Reviews of Modern Physics, v. 57, n. 2, p. 437-470, 1985.

8. Moulin, P.; Huntz, A.M.; Lacombe, P. Acta Met., n. 28, p. $745,1980$.

9. Ben Abderrazik, G.; Moulin, G.; Huntz, A.M. Oxid. Met., v. 33, n. 3-4, p.191 and 237, 1990.

10. Moulin, P. Doctor Thesis, University Paris XI, 1978.

11. Tsaï, S.C. Doctor Thesis, University Paris XI, 1996.

12. Calvarin Amiri, G. Doctor Thesis, University Paris XI, 1998.

13. Rabbani, F.; Ward, L.P.; Strafford, K.N. Oxid. Met., 54, n. 1-2, p. 139-153, 2000. 